\title{
The Effect of Methotrexate in Rheumatoid Arthritis Patients is Reduced by Tea Consumption
}

\author{
Ehab M. Mikhael*, Samer I. Mohammed \\ University of Baghdad, College of Pharmacy, Clinical Pharmacy Department, Bagdad,Iraq \\ *Corresponding author: ehab_pharma84@yahoo.com
}

Received May 09, 2013; Revised May 23, 2013; Accepted May 24, 2013

\begin{abstract}
Rheumatoid arthritis (RA) is a common inflammatory disease. Methotrexate (MTX) is the most important drug for RA treatment; it acts as anti inflammatory drug by increasing adenosine level. Adenosine receptor antagonists reduce the anti inflammatory effect of MTX. Tea is a popular drink in Iraq contain large amount of caffeine, this study aimed to evaluate the effect of tea consumption on the response to MTX in RA patients. A cross-sectional study was conducted in Baghdad Teaching Hospital, Rheumatology Unit from September 2012 to April 2013. A total of 25 RA patients (5 males and 20 females) who were treated by using MTX for at least 3 consecutive months and drink tea daily were included in this study. RA Disease activity was assessed in all patients by clinical disease activity index (CDAI). A direct interview with all patient were done, each patient was asked about their tea intake and the size of cup used. This study showed that the average consumption of tea per day for each patient was approximated to 8 small cups, this high level of consumption was associated with a high value of RA disease activity as measured by CDAI in greater than the half of patient who participated in this study. There is a direct positive correlation between evaluator global assessment and swelling joint count with tea consumption. In conclusion tea consumption decreases the effectiveness of MTX in Iraqi patients with rheumatoid arthritis.
\end{abstract}

Keywords: rheumatoid arthritis, methotrexate, adenosine, disease activity, tea

\section{Introduction}

Rheumatoid arthritis (RA) is a common systemic inflammatory disease of unknown etiology [1]. Methotrexate (MTX) is one of the most important drugs for the standard care and the management of RA [2]. The most acceptable explanation of the anti-inflammatory mechanism of MTX is through the inhibition of 5aminoimidazole-4-carboxamide ribonucleotide (AICAR) transformylase enzyme, this inhibition lead to intracellular AICAR accumulation, and since AICAR inhibits AMP deaminase and adenosine deaminase, AICAR accumulation could lead to the release of AMP (which may be dephosphorylated to adenosine) and/or adenosine [3]. Adenosine is a potent endogenous antiinflammatory mediator which acts by binding to specific receptors on the surface of lymphocytes, monocytes, and neutrophils, to down regulates inflammatory pathways $[3,4,5,6]$. It was found that adenosine receptor antagonists like caffeine and deletion of adenosine receptors reduce the antiinflammatory response to methotrexate not only in animal studies but also in clinical trials for patients with rheumatoid arthritis [7,8,9].

Tea is one of the most popular drinks in the world [10] and especially in Iraq [11]. Different types of tea that usually consumed in Iraq contains large amount of caffeine [12]. However till now there is no any study to assess the effect of tea consumption on MTX, so this study aimed to evaluate the effect of tea consumption on the response to MTX in RA patients.

\section{Methods}

A cross-sectional study was conducted in Baghdad Teaching Hospital, Rheumatology Unit from September 2012 to April 2013. A total of 25 RA patients (5 males and 20 females) who were treated by using MTX for at least 3 consecutive months and drink tea daily were included in this study. Patients were diagnosed to have RA by rheumatologist according to revised 1987 American College of Rheumatology (ACR) classification criteria for RA [13]. Patients with diseases other than rheumatoid arthritis were excluded from the study. Demographic data of patients were reported regarding their age, gender, duration of the disease, and medication history (Table 1).

RA Disease activity was assessed in all patients by clinical disease activity index (CDAI), which was shown to be a valid and reliable measure for assessment of Iraqi patients with active RA(14). It was measured by palpation of bilateral knees, shoulders, elbows, wrists, metacarpophalangeal and proximal interphalangeal joints, to count the number of tender (TJC) and swelling joints (SJC). Patient (VAS) and physician global assessment (EGA) were also measured using visual analogue scale VAS of $0-10 \mathrm{~cm}$.

$\mathrm{CDAI}=\mathrm{TJC}+\mathrm{SJC}+\mathrm{VAS}+\mathrm{EGA}$ CDAI values less than 2.8 considered as remission; $\mathrm{CDAI}>2.8 \leq 10$ 
considered as low disease activity; CDAI $>10 \leq 22$ considered as moderate disease activity; CDAI $>22$ considered as high disease activity.

Table 1. Demographic, drug and clinical data of patients

\begin{tabular}{|c|c|}
\hline Parameter & Value \\
\hline Age ( years) & $52.36 \pm 11.78$ \\
\hline Female percent & $80 \%$ \\
\hline Duration of RA ( years) & $11.76 \pm 10.37$ \\
\hline Onset of using MTX ( Years) & $3.6 \pm 2.43$ \\
\hline Dose of MTX (mg/week) & $13.4 \pm 3.54$ \\
\hline $\begin{array}{c}\text { Amount of tea consumption ( Approximate } \\
\text { consumption using small east tea can) }\end{array}$ & $8.04 \pm 3.7$ \\
\hline TJC & $9.44 \pm 5.54$ \\
\hline SJC & $2.56 \pm 2.02$ \\
\hline VAS & $6.4 \pm 1.76$ \\
\hline EGA & $5.4 \pm 1.63$ \\
\hline CDAI ( RA disease activity) & $23.8 \pm 8.64$ \\
\hline
\end{tabular}

MTX: Methotrexate; TJC: Tender Joint count; SJC: Swelling Joint count; VAS: Visual analogue scale; EGA: Evaluator global assessment; CDAI: Clinical disease activity index

A direct interview with all patient were done, each patient was asked about their tea intake and the size of cup used; Tea intake was defined by the number of cups of tea, measured on a daily basis, rather than mg of caffeine, introducing variability of caffeine content into the analysis; Cup size was defined either as small cup (east tea can) or large cup (Glass or Mug). The capacity of different glasses and mugs from Iraqi market were calculated, and it was found to be approximately equal to $180-250 \mathrm{ml}$, furthermore the capacity of different types of east tea cans in Iraqi market were calculated and was found to be approximately equal to $60-80 \mathrm{ml}$. So for easy calculation each one large cup considered equal to three small cups.

\section{Statistical Analysis}

SPSS version 12 was used for data input and analysis. Shapiro wilk test was used to check data normality of distribution. Chi square test for independence used to test the significance of association between discrete variables. Pearson correlation coefficient was used to assess the correlation between normally distributed continuous variables, and spearman correlation coefficient was used for abnormally distributed data. All p values used were asymptotic and two sided. Values with $\mathrm{p}<0.05$ were considered significant.

\section{Results}

This study showed that most patients were females with long history not only of RA but also with the use of MTX as shown in Table 1 . The average consumption of tea per day for each patient was approximated to 8 small cups (east tea cans), this high level of consumption was associated with a high value of RA disease activity as measured by CDAI in greater than the half of patient who participated in this study as shown in Table 1 and Table 2. Additionally Table 2 showed that there is a statistically significant difference in the between patients with high RA disease activity and those with mild - moderate RA disease activity. Table 3 showed that only evaluator global assessment and swelling joint count were directly and significantly correlated with tea consumption. Whereas
Table 4 showed no any significant correlation between the duration of RA disease or MTX usage and RA disease activity.

Table 2. Number of RA patients according to their disease activity

\begin{tabular}{|c|c|c|c|}
\hline $\begin{array}{c}\text { Low disease } \\
\text { activity } \\
\text { Number (\%) }\end{array}$ & $\begin{array}{c}\text { Moderate disease } \\
\text { activity } \\
\text { Number (\%) }\end{array}$ & $\begin{array}{c}\text { High disease } \\
\text { activity } \\
\text { Number (\%) }\end{array}$ & $\begin{array}{c}\mathrm{P} \\
\text { Value }\end{array}$ \\
\hline $2(8)$ & $10(40)$ & $13(52)$ & 0.02 \\
\hline
\end{tabular}

Table 3. Correlation between tea consumption and clinical parameters of RA disease activity

\begin{tabular}{|c|c|c|}
\hline Parameter & Correlation coefficient & P value \\
\hline TJC & 0.154 & 0.464 \\
\hline SJC & 0.439 & 0.028 \\
\hline VAS & 0.188 & 0.369 \\
\hline EGA & 0.459 & 0.021 \\
\hline CDAI & 0.334 & 0.103 \\
\hline
\end{tabular}

TJC: Tender Joint count; SJC: Swelling Joint count; VAS: Visual analogue scale; EGA: Evaluator global assessment; CDAI: Clinical disease activity index

Table 4. Correlation between RA disease activity with duration of RA and MTX usage

\begin{tabular}{|c|c|c|}
\hline Parameter & $\begin{array}{c}\text { Correlation } \\
\text { coefficient }\end{array}$ & P value \\
\hline Duration of RA ( years) & -0.111 & 0.597 \\
\hline Onset of using MTX (years) & 0.052 & 0.806 \\
\hline
\end{tabular}

\section{Discussion}

This study showed that Iraqi patients consume large amount of tea, this result can be explained by the Iraqi habit of tea consumption after each meal, additionally this explanation can be linked with a fact that Iraq as a country import tea more than many of the Arabic and Asian countries [15]. MTX is one of the most commonly used and effective DMARDs for the treatment of RA when used as monotherapy or added to other DMARDs [16], but in this study no any patient was in remission and only $8 \%$ of patients had low RA disease activity, and the majority of patients $52 \%$ had high disease activity, which can be explained by the negative effect of caffeine that present in the consumed tea on MTX effectiveness, similarly many other studies found that caffeine decrease response to MTX $[8,9,17]$; Yet, another study [18] in this regard showed that caffeine intake don't affect MTX efficacy. Although that study was larger than the current study, but it had many limitations, since the amount of tea consumed by patients who participated in that study was only slightly more than the usual intake, while in the current study participated patients consume very large amount of tea per day. The second limitation of that study is that many participated patients were not using MTX only, while in the current study all patients were using MTX. Since some studies found that the response to MTX is decreased by long duration of RA $[17,18,19]$, and other studies found that about one third of patients don't have a good response to MTX after long period of follow up. (***-20) A confirmation of the current study results was done, by evaluating the correlation between RA disease activity and both duration of RA and MTX usage, the statistical results showed a non significant correlation between RA disease activity and duration of RA or MTX usage; besides that $92 \%$ of patients in the current study don't have a good response to MTX; this results mean that 
tea rather than any other factor decrease the effect and response to MTX.

The results of this study showed that although participated patients had a high values TJC and VAS, but they were not correlated with tea consumption, and only SJC and EGA were directly correlated with tea consumption. Both SJC and EGA are considered more reliable indicators for assessing and detection the response to drug therapy in RA patients and even more reliable than VAS and SJC [21,22]. This result further confirms our finding of the negative effect of tea consumption on the effectiveness of MTX. Disease activity as measured by CDAI was modestly correlated with tea consumption, yet it didn't achieve statistical significance. Similarly Saevarsdottir [19] etal found that there is no correlation between disease activity as measured by DAS28 and caffeine consumption. The lack of statistical significance may be attributed to the small sample size in the current study, and the lack of correlation between tea consumption and 2 of the 4 RA disease indices (TJC and VAS) that used in CDAI calculation.

In conclusion, tea consumption decreases the effectiveness of MTX in Iraqi patients with rheumatoid arthritis.

\section{Reference}

[1] Cojocaru M, Cojocaru IM, Silosi I, Vrabie CD, Tanasescu R. Extra-articular manifestations in rheumatoid arthritis. Maedica (Buchar), 5:286-91. Dec. 2010.

[2] Brauna J, Rau R. An update on methotrexate. Curr Opin Rheumatol, 21(3):216-23. May. 2009.

[3] 3. Cronstein BN. Low-dose methotrexate: a mainstay in the treatment of rheumatoid arthritis. Pharmacol Rev. 57(2):163-72. Jun. 2005.

[4] Cutolo M, Sulli A, Pizzorni C, Seriolo B, Straub RH. Antiinflammatory mechanisms of methotrexate in rheumatoid arthritis. Ann Rheum Dis, 60:729- 735. Aug. 2001.

[5] Cronstein BN, Naime D, Ostad E. The antiinflammatory mechanism of methotrexate: increased adenosine release at inflamed sites diminishes leukocyte accumulation in an in vivo model of inflammation. J Clin Invest. 92(6):2675-82. Dec.1993.

[6] Morabito L, Montesinos MC, Schreibman DM, Balter L, Thompson LF, Resta R, Carlin G, Huie MA, Cronstein BN. Methotrexate and sulfasalazine promote adenosine release by a mechanism that requires ecto-5'-nucleotidase-mediated conversion of adenine nucleotides. J Clin Invest, 101(2):295-300. Jan. 1998.

[7] Biaggioni I, Paul S, Puckett A, Arzubiaga C. Caffeine and theophylline as adenosine receptor antagonists in humans. $J$ Pharmacol Exp Ther. 258(2):588-93. Aug. 1991.
[8] Montesinos C, Yap JS, Desai A, Posadas I, McCrary CT, Cronstein BN. Reversal of the antiinflammatory effects of methotrexate by the nonselective adenosine receptor antagonists theophylline and caffeine. Evidence that the antiinflammatory effects of methotrexate are mediated via multiple adenosine receptors in rat adjuvant arthritis. Arthritis Rheum. 43(3):656-63. Mar. 2000.

[9] Nesher G, Mates M, Zevin S. Effect of caffeine consumption on efficacy of methotrexate in rheumatoid arthritis. Arthritis Rheum. 48(2):571-2. Feb. 2003.

[10] Matthews CM. Steep your genes in health: drink tea. Proc (Bayl Univ Med Cent). 23(2):142-4. Apr. 2010.

[11] Mahamood HY. Estimation of Lead in some of foods and drinks common popular in Basrah city - Iraq. Diyala Agricultural Sciences, 3 (1); 101-106. 2011.

[12] Hamad MN, Abdul-Hussain DA. Gravimetric Estimation of Caffeine in Different Commercial Kinds of Tea Found in the Iraqi Market. Iraqi J Pharm Sci, 19(2); 48-53. 2010.

[13] Arnett FC, Edworthy SM, Bloch DA, McShane DJ, Fries JF, Cooper NS, Healey LA, Kaplan SR, Liang MH,Luthra HS, et al. The American Rheumatism Association 1987 revised criteria for the classification of rheumatoid arthritis. Arthritis Rheum. 31(3):315-24. Mar. 1988.

[14] 14. Gorial FI. Validity and reliability of CDAI in comparison to DAS28 in Iraqi patients with active rheumatoid arthritis. J Fac Med Baghdad. 54 (3); 231-33. 2012.

[15] Alastair Hicks. Current Status and Future Development of Global Tea Production and Tea Products. AU J.T. 12(4): 251-264. Apr. 2009.

[16] Evripidis Kaltsonoudis, Charalampos Papagoras, Alexandros A Drosos. Current and Future Role of Methotrexate in the Therapeutic Armamentarium for Rheumatoid Arthritis. Int J Clin Rheumatol. 7(2):179-189. 2012.

[17] Silke C, Murphy MS, Buckley T, Busteed S, Molloy MG, Phelan $M$. The effect of caffeine ingestion on the efficacy of methotrexate [abstract]. Rheumatology Oxford, 40 Suppl:34. 2001.

[18] Benito-Garcia E, Heller JE, Chibnik LB, Maher NE, Matthews HM, Bilics JA, Weinblatt ME, Shadick NA. Dietary caffeine intake does not affect methotrexate efficacy in patients with rheumatoid arthritis. J Rheumatol. 33(7):1275-81. Jul. 2006.

[19] Saevarsdottir S, Wallin H, Seddighzadeh M et al. SWEFOT Trial Investigators Group. Predictors of response to methotrexate in early DMARD naive rheumatoid arthritis: results from the initial open-label phase of the SWEFOT trial. Ann. Rheum. Dis.70,469475. 2011.

[20] Weinblatt ME, Kaplan H, Germain BF, Block S, Solomon SD, Merriman RC, Wolfe F, Wall B, Anderson L, Gall E, et al. "Methotrexate in rheumatoid arthritis: a five-year prospective multicenter study. Arthritis Rheum. 37(10):1492-8. Oct. 1994.

[21] Rohekar G, Pope J. Test-retest reliability of patient global assessment and physician global assessment in rheumatoid arthritis. J Rheumatol. 36(10):2178-82. Oct. 2009.

[22] Soubrier M, Zerkak D, Gossec L, et al. Which variables best predict change in rheumatoid arthritis therapy in daily clinical practice?. J Rheumatol. 33(7):1243-6. Jul. 2006. 